\title{
Relationship between service recovery, customer satisfaction and customer loyalty: Empirical evidence from e-retailing
}

\author{
Anh Chi Phan ${ }^{a^{*}}$, Ha Thu Nguyen ${ }^{a}$ and Thoa Xuan Thi Pham ${ }^{b}$
}

${ }^{a}$ University of Economics and Business, Vietnam National University, Hanoi, Vietnam

${ }^{b}$ Yokohama National University (YNU), Japan

\section{H R O N I C L E}

\begin{tabular}{l}
\hline Article history: \\
Received October 2, 2020 \\
Received in revised format \\
November, 10, 2020 \\
Accepted December 202020 \\
Available online \\
December 242020 \\
\hline Keywords: \\
Service recovery \\
Interactive fairness \\
Procedural fairness \\
Customer satisfaction \\
e-retailing \\
Vietnam
\end{tabular}

\section{A B S T R A C T}

This paper presents the results of an empirical study on the relationship between service recovery quality, customer satisfaction and loyalty in Vietnam's e-retailing. Structural Equation Modelling (SEM) is applied to analyze the data collected from experienced customers in online shopping in Vietnam from November 2018 to March 2019. The results of statistical analysis indicate that interactive fairness, outcome fairness, procedural fairness significantly impact on customer satisfaction which then increases customer loyalty. This study suggests that customer's ability to locate and interact with technical support on a website and how a company treats the customer would significantly decide satisfaction and loyalty from customer. E-retailers in developing economies should consider service recovery process as the opportunity to gain customers' purchase intentions.

\section{Introduction}

Since 2000s, the internet has grown exponentially that has made online shopping or e-retailing become easier, cheaper and more accessible to manage transactions electronically. Thus, the trend of shopping online is rapidly increasing as a preferred way of shopping for customers all over the world. Service providers cannot avoid failing to satisfy consumers' everincreasing demands during service delivery, and they are not capable to totally prevent all service failures, which refers to unexpected risks during purchasing. It was found that switching brands, negative worth of mouth normally came from unsatisfied consumers (Miller et al., 2000). Thus, increasing research and business attention have been given to service recovery, which refers to how service providers respond to a service failure (Gronroos, 1988) as a significant marketing strategy to retain customers and maintain a relationship with customers. The separation of customer and retailer during an online transaction highlights the importance of service recovery in managing e-service. The compensation policy for solving customers' complaints is important aspects to evaluate e-service quality (Collier \& Bienstock, 2006; Proserpio \& Zervas, 2017; La \& Choi, 2019; Van Vaerenbergh et al., 2019). Interestingly, Mccollough (2000) has proposed a concept of "recovery paradox" that talked about experienced customer with service failure and followed by superior recovery exhibit behavioural intentions towards the service provider, then they are more favourable than they would have no failure occurred. The service recovery is also expected as a good chance to a secondary satisfaction when customers have a comparison between their expectations and their recovery quality perceptions (De Matos et al., 2007). If the perceptions are greater than expectations, the secondary satisfaction has chances to become greater than satisfaction before the failure. Determining the relative effects of different types of service recovery on consumer satisfaction will provide significant strategic that helps for marketers seeking to find more effective and efficient recovery policies for their target consumers in the online market (Jung \& Seock, 2017).

* Corresponding author

E-mail address: hant@vivnu.edu.vn (H.T. Nguyen)

(C) 2021 by the authors; licensee Growing Science. doi: $10.5267 /$ j.uscm.2020.12.007 
Previous studies have expanded knowledge on conceptualisation and measurement of e-service recovery quality (Collier \& Bienstock, 2006; Sousa \& Voss, 2009; Kuo \& Wu, 2012; Zhang et al., 2015). However, further studies need to be performed in this field to enlarge the existing literature. Because formative indicators were used in previous studies, need to be arranged into descriptive dimensions of rigour and relevant service recovery's aspects so that we can understand better about relevant factors that might have different influences on customer satisfaction. In that way, service recovery dimensions in e-retailing would be evaluated more specifically and independently so that practical implications will be properly delivered. Especially in developing countries, where the online markets have been expanding recently, and e-retailers now have innovative ways of operation to improve their business performance, including service recovery.

Vietnam is currently viewed as a promising land of e-retailing industry because of its young population, high internet penetration rate, climbing smartphone penetration rates. By 2018, the consumer value of online purchasing in Vietnam was US\$ 6 billion, which increased more US\$1 billion than the value for 2017. Vietnamese government reports indicates that 59 million internet users in Vietnam and they spent USD \$2.2 billion to buy consumer goods such as are fashion, electronics, toy, and groceries online in 2018 (General Statistics Office of Vietnam, 2019). The evolution of e-commerce in Vietnam is regarded as in developing stages and e-service quality became an emerging issue that concerns both buyers and sellers. Many service providers became more focused on improving service quality including product quality, service reliability, responsiveness, and customer care. Service quality has significant impacts on customer trust, and satisfaction (Liang \& Nguyen, 2018; Pham et al., 2018; Yongrok Choi \& Do Mai, 2018; Giao, Vuong \& Quan, 2020). Recently, because of significant incensement of online shopping transaction in Vietnam, after-sale service became an important aspect for any service provider. Online sellers need to manage customer feedback, handle customer complaints, compensation, and apologies in case of service failure. While previous studies indicate the significant impact of service quality practices, the number of an empirical study on impact after sell quality it is very limited and scholars should go further in investigating the current situation of service recovery practices in online shopping and its impacts on customer perception and behaviors in developing economies. To address this need, this study is conducted to investigate the effectiveness of service recovery dimensions in the market of Vietnam e-retailing. We used Structural Equation Modelling (SEM) to analyze the data collected via the questionnaire survey in Vietnam. The results of statistical analysis indicate that interactive fairness, outcome fairness, procedural fairness significantly impact on customer satisfaction which then increases customer loyalty in online shopping.

This paper is organised as follows. A literature review on service recovery measurement is presented in the second section, followed by an analytical framework and hypotheses establishment. The third section explains methodology application and measurement scales used in this study. The analytical results are shown in the next part. The fifth section gives some main findings, implication and discussion. The limitations of this study, future research, conclusion will be presented in the last sections.

\section{Literature review and hypothesis development}

The conceptual definition of service quality developed the first steps in the eighteens last century by (Parasuraman at al., 1988). They have been long noted the comparison service encounters and customers. As online shopping has started in early $21^{\text {st }}$ century, the author continued to develop this concept into e-retailing context. E-service quality is defined by the extent of efficiency and effectiveness an e-retailer offers to customers, and the quality could be evaluated in the way of purchasing, and delivery of products and services (Parasuraman et al., 2005). After that, other researchers developed and presented various models for e-service quality. Each model and research have its dimensions based on customer experience perspective or evaluation perspective. However, most studies primarily focused on the process quality, that is, the interaction of the customer and the website. From the customer's perspective, service failure refers to any situation where something has gone wrong regarding the service received. Service recovery indicates quality of what and how retailers respond to customers when they make complaints for some problems of service failure (Sousa and Voss, 2009). Empathy and apology is needed for psychology (Parasuraman at al., 2005; Collier \& Bienstock, 2006; Kassim \& Asiah Abdullah, 2010; Jung \& Seock, 2017) while tangible recovery offers physical compensation for customers' real damages (Chou, 2015; Zhang et al., 2015). Table 1 summarises some main empirical studies on service recovery since 2005.

Table 1

Summary of empirical studies on e-service recovery

\begin{tabular}{|c|c|c|c|}
\hline & $\begin{array}{l}\text { Operationalization of } \\
\text { service recovery }\end{array}$ & $\begin{array}{l}\text { Data, Country, } \\
\text { Analytical technique }\end{array}$ & Main findings \\
\hline Ahn at al. 2004 & Responsiveness & $\begin{array}{l}\text { - Online questionnaires survey by } 932 \\
\text { customers, e-retailing in Korea } \\
\text { - SEM. }\end{array}$ & $\begin{array}{l}\text { - Quality in online service had a positive influence on ease of use and } \\
\text { usefulness; } \\
\text { - Offline quality positively impacted on usefulness. }\end{array}$ \\
\hline $\begin{array}{l}\text { Parasuraman et al. } \\
2005\end{array}$ & $\begin{array}{l}\text { Responsiveness; } \\
\text { Compensation; } \\
\text { Contact }\end{array}$ & $\begin{array}{l}\text { - Online questionnaires survey by } 549 \\
\text { customers, e-retailing in the US. } \\
\text { - SEM. }\end{array}$ & $\begin{array}{l}\text { - E-S-QUAL consists of a } 22 \text {-item scale of efficiency, fulfilment, system } \\
\text { availability, and privacy; } \\
\text { - E-RecS-QUAL was } 11 \text { items of responsiveness, compensation, and } \\
\text { contact. }\end{array}$ \\
\hline Lee and Lin, 2005 & Responsiveness & $\begin{array}{l}\text {-Questionnaires survey by } 305 \text { students, } \\
\text { online shopping bookstore in Taiwan. } \\
\text {-SEM. }\end{array}$ & $\begin{array}{l}\text { - Website design, reliability, responsiveness, trust affected overall service } \\
\text { quality and customer satisfaction which then significantly related to } \\
\text { repurchase intentions. }\end{array}$ \\
\hline $\begin{array}{l}\text { Collier and } \\
\text { Bienstock, } 2006\end{array}$ & $\begin{array}{l}\text { Interactive fairness; } \\
\text { Procedural Fairness; }\end{array}$ & $\begin{array}{l}\text { - Questionnaires survey by } 266 \\
\text { students, e-retailing in the USA. }\end{array}$ & $\begin{array}{l}\text { - Transaction outcome quality subsequently affected satisfaction } \\
\text { evaluations; }\end{array}$ \\
\hline
\end{tabular}



quality to behavioural intentions.

- A sincere apology, promptness, explanation, attentiveness, redress will have a significant positive influence on complainant satisfaction.

- Complainant satisfaction will exert a significant positive influence on repurchase intention and a significant negative influence on negative WOM intention.

- Repurchase intentions will exert a significant negative influence on negative WOM intention.

- The asscociation between failure severity and satisfaction was moderated by firm reputation, and resulted in higher repurchase intentions following service failures;

- Ascriptions of controllability and stableness were associated with repurchase behaviours, satisfaction did not fully mediate these relationships.

- Service failures had a negative effect on customer loyalty intentions, problem resolution leads to increased loyalty;

- Outstanding recovery resulted in loyalty intentions which were more favourable than they would be had no failure occurred.

- Perceived service quality significantly impacted on customer satisfaction which in turn significantly affected on trust;

- Both customer satisfaction and trust impacted significantly on word of mouth, which then leaded to repeat visits or repurchase intentions.

- The speed of download has a negative relationship with site functionality as the only non-linearity for e- retailers.

- Improving relationships with customers through more effective use of customer relationship management system and the related policy could improve performance on these dimensions.

- Distributive justice increased positive emotions and decreased negative ones;

- Procedural justice enhanced post-recovery satisfaction, increases positive emotions and decreases negative ones;

- Interactional justice increased post-recovery satisfaction;

- Positive emotions increased post-recovery satisfaction, and vice versa, post-recovery satisfaction positively affected post-purchase intentions.

- E-retailers needed to pay attention to establishing an integrated recovery system that could facilitate employee job satisfaction and organisational citizenship behaviour, ultimately the e-retailer's market performance;

- The impacts of job satisfaction on organizational citizenship behaviour and market performance were found to be low.

- The relationships between severity of service failure and coping strategies, customer satisfaction and repurchase intentions were moderated by brand reputation.

- Service recovery positively impacted on attitude and behaviour loyalty, and service failure positively impacted on service recovery;

- Both apology and compensation partially mediated the relationship between delivery failure and attitude loyalty and behaviour loyalty. Since service guarantee is one important consideration of high uncertainty avoidance in Chinese culture, e-retailers should more focus on process quality and service recovery.

- Process guidelines and compensation guidelines associated with recovery approaches influence recovery efficacy;

- Empowerment moderated the relationship between process guidelines and recovery efficacy, compensation guidelines and recovery efficacy;

- Recovery has positive moderation roles for the relationship between behaviour guidelines and recovery efficacy;

- There were interrelationships among recovery efficacy, recovery accountability, and recovery performance.

\begin{tabular}{|c|c|c|c|}
\hline Balaji et al. 2017 & $\begin{array}{l}\text { Perceived injustice; } \\
\text { Emotion; Suppression; } \\
\text { Reappraisal }\end{array}$ & $\begin{array}{l}\text { Questionnaires survey by } \\
305 \text { customers, e-retailing in } \\
\text { Malaysia. } \\
\text {-SEM. }\end{array}$ & $\begin{array}{l}\text { - Positive and negative emotions have mediation roles for the interaction } \\
\text { between perceived injustice and satisfaction from customers; } \\
\text { - The emotion regulation of customers impacted the relationships between } \\
\text { satisfaction and negative word of mouth and behaviour intentions. }\end{array}$ \\
\hline $\begin{array}{l}\text { Jung and Seock, } \\
2017\end{array}$ & Apology; Compensation & $\begin{array}{l}\text {-Questionnaires survey by } 368 \\
\text { customers, e-retailing in the US. } \\
\text {-Manova, multiple regression analysis. }\end{array}$ & $\begin{array}{l}\text { - Distributive and interactional justice differed by the types of service } \\
\text { recovery due to consumers particularly favour apology among types of } \\
\text { service recovery. } \\
\text { - The relationships between perceptions of justice, satisfaction, and word } \\
\text { of mouth were mediated by service recovery. }\end{array}$ \\
\hline $\begin{array}{l}\text { Wang and Zhang, } \\
2018\end{array}$ & $\begin{array}{l}\text { Online service failure } \\
\text { severity }\end{array}$ & $\begin{array}{l}\text {-Questionnaires survey by } \\
102 \text { customers, e-retailing in China. } \\
\text {-SEM. }\end{array}$ & $\begin{array}{l}\text { - Customers exposed to very bad failures have lower satisfaction than } \\
\text { customers exposed to mild failures in online shopping, but they show a } \\
\text { similar level of offline loyalty in both degrees of online service failure. }\end{array}$ \\
\hline Cheng et al. 2019 & $\begin{array}{l}\text { Distributive Justice; } \\
\text { Procedural Justice; } \\
\text { Interactional Justice }\end{array}$ & $\begin{array}{l}\text {-Questionnaires survey by } 442 \\
\text { Malaysians and international tourists, } \\
\text { hotel industry in Malaysia. } \\
\text { - CPA, SEM. }\end{array}$ & $\begin{array}{l}\text { - Perceived justices have a positive and direct effect on customer } \\
\text { satisfaction. } \\
\text { - Reaffirms the relationship between customer satisfaction and loyalty. }\end{array}$ \\
\hline
\end{tabular}

However, most of the previous studies investigated recovery as an overall aspect to evaluate overall e-service quality. We know a little about the specific roles of service recovery on improving customer behaviours. Previous studies often examine service recovery in a limited number of specific dimensions so that researchers and practices hard to understand thoroughly 
about the impact of each e-service recovery practices. E-service is rapidly expanding over the last decade and its need to reexamine the effectiveness of service recovery in the context of emerging economies such as Vietnam. The gap emphasizes the need for investigating how recovery quality has roles in improving customer intensions.

Adopting the conceptual framework developed by Collier and Bienstock (2006), the authors examine three important perspectives of e-service recovery interactive, procedural and outcome fairness.

- Interactive fairness refers to the ability to locate and interact with customers by technical support on a website, such as the ability to give questions or write comments, an e-mail address where customers can voice a problem or a concern, easy access to telephone numbers of operators at the company that can assist the customer.

- Procedural fairness refers to a company's return policy, the buyer's rights in the case of fraudulent charges, and how quick a problem can be resolved.

- Outcome fairness includes such issues as monetary compensation, future free services, or an apology.

The overall analytical framework of this study is presented in Fig. 1.

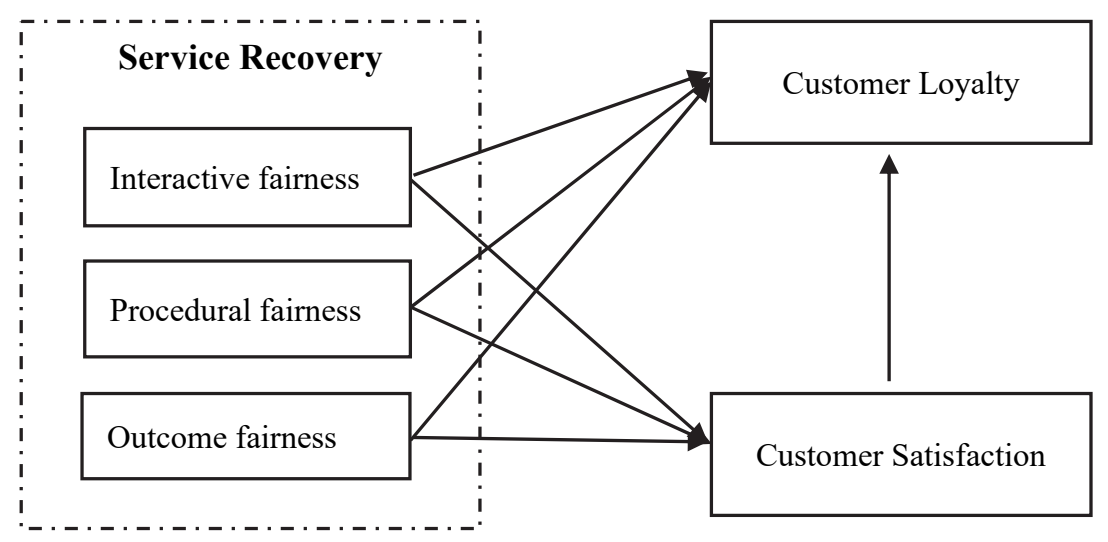

Fig. 1. Analytical framework

Interactive fairness concerns with the interaction of company with the customer via website, phone, and e-mail. Are e-mail replies written in a condescending tone or with a sense of empathy that the problem occurred? What is the tone of telephone conversations between employees and customers who call to resolve a problem? The interactive fairness is one of the most high-profile areas that can make a customer satisfied or dissatisfied during the transaction process. Chou (2015) proposed that the effect of the retailer's response to the service failure resulted in their relationship with the retailer was either weakened or broken. Previous studies demonstrated that interactive fairness would impact the level of satisfaction and loyalty from customer in the context of online shopping (Balaji et al., 2017). Thus, the first two hypotheses can be stated as follows:

$\mathbf{H}_{1}$. There is a positive relationship between interactive fairness and customer satisfaction.

$\mathbf{H}_{2}$. There is a positive relationship between interactive fairness and customer loyalty.

The second first-order dimension that makes up the e-service recovery construct is procedural fairness that refers to the process of handling compaints. This area has a high impact on the evaluation of service quality because "justice delayed is justice denied" in the mind of customer (Wang and Zhang, 2018). Effective procedural fairness would lead to customer satisfaction, positive word-of-mouth, repeat purchase, and loyalty. It is, therefore, hypothesized that:

H3. There is a positive relationship between procedural fairness and customer satisfaction.

$\mathbf{H}_{4}$. There is a positive relationship between procedural fairness and customer loyalty.

The third first-order dimension of service recovery is outcome fairness concerning with monetary compensation, future free services, or an apology. When making complain, customer wants to be compensated equitably for any inconvenience and should meet the customer's expectations of compensation. Consumers are likely to compare their perceptions of online service outcomes with their pre-established level of expectation, and satisfaction occurs when their evaluation is higher than their pretrial expectation; otherwise, dissatisfaction occurs. If companies do have a service failure, they must offer to customers good recovery policies (returning items, guarantee, compensation...) to avoid a "double deviation" from 
customer expectations and leads to increased satisfaction and loyalty behavior. This leads to the establishment of the fifth and sixth hypotheses as follow:

H5. Outcome fairness has a positive impact on customer satisfaction.

H6. Outcome fairness has a positive impact on customer loyalty.

Previous studies indicate the significant impact of customer satisfaction on customer loyalty. The higher level of customer satisfaction would lead to the higher the probability of repurchasing (Ekiz and Arasli, 2007). Several scholars such as Lee and Lin (2005), Sousa and Voss (2009), Balaji et al. (2017) indicate resultes that recovery quality positively influenced customer satisfaction that leads to loyalty. The seventh hypothesis could be established as follows.

\section{H7.Customer satisfaction has a positive impact on customer loyalty.}

The next section present data collection and analysis to test established hypotheses.

\section{Data collection and Measurement Test}

A questionnaire survey was conducted in Hanoi from November 2018 to March 2019. The survey respondents are the online buyer who ever had service recovery experience in online shopping in Vietnam. To test the impact of service recovery on customer satisfaction and loyalty, five scales are operationalized: interactive fairness, procedural fairness, outcome fairness, customer satisfaction and customer loyalty.Three scales measure service recovery was adapted from Collier and Bienstock (2006). Customer satisfaction and customer loyalty scales were adapted from the question items suggested by (Collier and Bienstock, 2006), Wicks and Roethlein (2009). The target respondents were asked to give the evaluation on questions and a five-point Likert scale from strongly disagree to strongly agree. We gave both pencil-and-paper questionnaire and online questionnaire and collected total of 850 questionnaires, and after cleaning missing data, there were 802 usable responses used in this study. The authors used SPSS and AMOS statistical software to analyze the collected data. The construct validity is determined through the Confirmatory Factor Analysis (CFA) test with the value of factor loading expected to be $\geq 0.5$. The Construct Reliability and Validity (discriminant and convergent validity) of the items were expected to be CR $\geq$ 0.7 and AVE $\geq 0.5$ (Hair et al., 2013). The Structural Equation Modelling (SEM) technique was used to examine the causal relationships in the model and hypothesized proposed. The results of the Goodness of Fit (GoF) test of the structural model using RMSEA value criteria below 0.08 with GFI, RFI, CFI, NFI, NNFI $\geq 0.9$.

\section{Data analysis}

\subsection{Descriptive Statistics}

Fig. 2 summarizes the characteristics of the survey respondents in terms of gender, age and income. The respondents were $36.65 \%$ male and $62.84 \%$ female. And $63.30 \%$ were between the ages of 25 and 40 , only $3.7 \%$ of respondents were over 55 . In addition, about $60 \%$ of respondents had income over $\$ 400 /$ month.

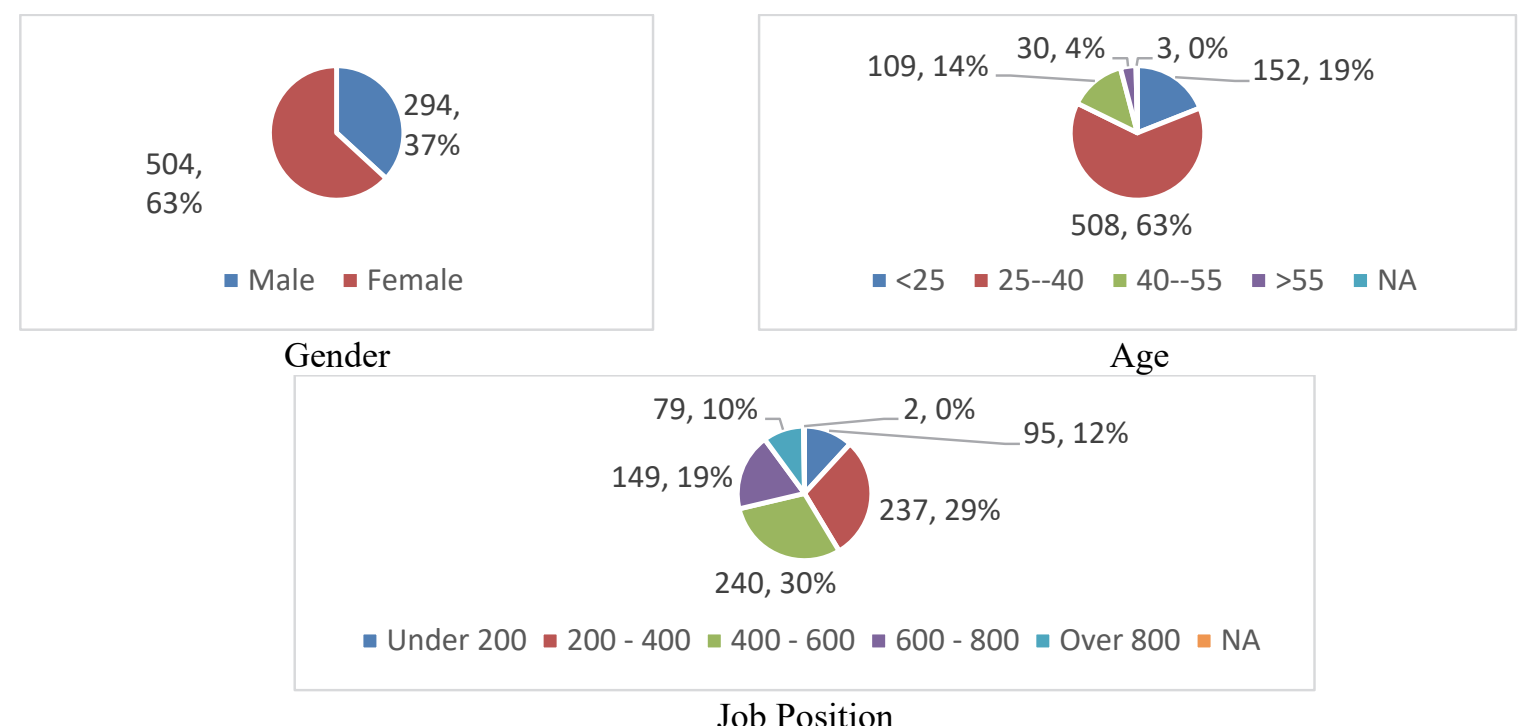

Fig. 2. The respondents' description

Note. NA: respondents did not answer to the question 


\subsection{Convergent and Discriminant tests}

The convergent validity and the discriminant validity were determined by the Composite Reliability, the Average Variance Extracted (AVE) and the factor loading indicators. Table 2 shows that the AVE values for all contructs that exceeded 0.50 , the composite reliability for all contructs $(\mathrm{CR}) \geq 0.80$, the factor loading (FL) for all items $\geq 0.70$. Hence, convergent validity and discriminant validity were achieved.

Table 2

Convergent validity and discriminant test

\begin{tabular}{|c|c|c|c|c|c|c|c|c|c|}
\hline \multirow[t]{2}{*}{ Variable } & \multirow[t]{2}{*}{ Mean } & \multirow[t]{2}{*}{ SD } & \multirow[t]{2}{*}{$\mathbf{C R}$} & \multirow[t]{2}{*}{ FL } & \multirow[t]{2}{*}{ AVE } & \multicolumn{4}{|c|}{ Correlation analysis } \\
\hline & & & & & & IF & OF & $\mathrm{PF}$ & $\mathrm{CS}$ \\
\hline Interactive Fairness & 3.657 & .700 & .932 & $.784-.825$ & .580 & 1 & & & \\
\hline Outcome Fairness & 3.679 & .747 & .843 & $.811-.861$ & .574 & .795 & & & \\
\hline Procedural Fairness & 3.734 & .739 & .920 & $.833-.860$ & .657 & .825 & .863 & & \\
\hline Customer Satisfaction & 3.809 & .718 & .840 & $.848-.887$ & .636 & .717 & .645 & .660 & \\
\hline Customer Loyalty & 3.789 & .743 & .863 & $.871-.900$ & .677 & .697 & .598 & .627 & .798 \\
\hline
\end{tabular}

Note. SD = Std Deviation; CR = composite reliability; FL = factor loading; AVE = average variance extracted

\subsection{Structural model and hypothesis test}

The proposed model provided an adequate fit to the data $\left(X^{2}=570.56 ; \mathrm{df}=292 ; X^{2} / \mathrm{df}=1.953 ; p<0.001 ; \mathrm{GFI}=0.919\right.$, RMSEA $=0.068$, TLI $=0.970$ and CFI $=0.985)$. Within the model, the estimates of the structural coefficients showed that the path between each construct was positive and significant. Table 3 summarizes the results of hypothesis testing :

Table 3

Hypotheses testing results

\begin{tabular}{lllc}
\hline Hypothesized relationship & S.R.W $\boldsymbol{\beta}$ & C.R & Conclusion \\
\hline H1. Interactive Fairness $\rightarrow$ Customer Satisfaction & 0.691 & 15.992 & Accepted \\
H2. Interactive Fairness $\rightarrow$ Customer Loyalty & 0.590 & 4.234 & Accepted \\
H3. Procedural Fairness $\rightarrow$ Customer Satisfaction & 0.129 & 3.689 & Accepted \\
H4. Procedural Fairness $\rightarrow$ Customer Loyalty & 0.131 & 8.723 & Rejected \\
H5. Outcome Fairness $\rightarrow$ Customer Satisfaction & 0.255 & 6.850 & Accepted \\
H6. Outcome Fairness $\rightarrow$ Customer Loyalty & 0.170 & 10.767 & Rejected \\
H7. Customer Satisfaction $\rightarrow$ Customer Loyalty & 0.918 & 13.313 & Accepted \\
\hline
\end{tabular}

Note. $*$ p-value $<0.001 ;$ S.R.W $=$ standardised regression weight; C.R $=$ critical ratio

- $\quad \mathrm{H} 1, \mathrm{H} 2, \mathrm{H} 3, \mathrm{H} 5$, and $\mathrm{H} 7$ should be accepted meaning that all recovery service dimensions impacted directly to customer satisfaction that then has a significant positive impacted to loyalty. In addition, only interactive fairness variable impacted directly to the loyalty of customers, thus supporting $\mathrm{H} 4$.

- The hypotheses of H4 and H6 should be rejected, showing the non-significant impact of procedural fairness and outcome fairness on customer loyalty.

\section{Main findings, implication and discussions}

This study investigates the role of a specific dimension of e-service recovery quality influencing consumer satisfaction and customer loyalty. The main findings of this study are summarized as follows:

- The analytical results indicate that e-service recovery quality plays a pivotal role in affecting consumer satisfaction \& loyalty. We found that interactive fairness, outcome fairness, procedural fairness significantly impacts on customer satisfaction which consequently leads to customer loyalty. That is in line with previous work in various consumption settings Collier and Bienstock, (2006), Sousa and Voss (2009), Kassim et al. (2010), Kuo and Wu (2012), Chou (2015), Zhang et al. (2015), Jung and Seock (2017), Wang and Zhang (2018). The results confirm the importance of after-sale service in online e-retailing in Vietnam. Besides the roles of product quality, company reaction when service failure additionally impacts to consumer attitude toward e-retailers. As the market of online shopping consumption has been added more emotional orientation, after-sale service and recovery action become an indispensable factor influencing the level of satisfaction and loyalty from shoppers.

- The analytical results show that interactive fairness has significant roles for customer satisfaction and customer loyalty. This suggests that customer's ability to locate and interact with technical support on a website and how a company treat the customer would significantly decide the level of satisfaction and loyalty from customer. The online buyer concern so much how service providers treat them and provide them adequate compensation when service failure. 
This study has contributions for quality research literature by examining the needs of service recovery on increasing the level of satisfaction and loyalty from purchasers under three types of fairness in e-service: interactive fairness, procedural and outcome fairness. It also provides new empirical evidence of the effectiveness of service recovery in the context of online shopping in Vietnam and some implications for service providers can be delivered based on analytical results.

Managers, as well as academics today, recognize the importance of service recovery quality in driving consumer's service evaluations and future purchase decisions. As suggested by Kasabov and Warlow (2010), service recovery is costly but desirable and necessary for service providers. This study indicates some lights into customers' satisfaction perception of retailer recovery efforts with online transactions if a service failure occurs. This study provides information about the voice of Vietnamese consumers showing that when a customer experiences a failure, the recovery measures used by the company will affect feelings of satisfaction. Online retailers must be prepared to handle the interactive, procedural, and distributive nature of service problems to maintain a high-quality perception with customers. The recovery measures in an online experience are often the last actions taken by an e-retailer to satisfy the customer. If an e-retailer fails to satisfy the consumer when a failure occurs, then the consumer ultimately leaves the online service experience dissatisfied, which will affect not only quality evaluations but also future behavioural intentions.

Interaction fairness will be implemented if employees' capabilities toward customer problem solving are improved. Today, the word is changing very fast, and customers want their purchasing problems to be solved as soon as possible. Since customers are unsatisfied with something and want to give complaints, they will be insensitive emotions. In such unhappy feelings, they could be easy to be angry or disappointed if company did not take care of them in the highest responsibility. Unsatisfied customers always want their emails could be replied within an hour and company could give them good compensations as so as possible. Employees need to be trained to ensure they show empathy with customers, apologising and sympathising even if they can't immediately solve a problem.

Regarding to procedural fairness, a retailer should make it as easy as possible to get in touch, offer a full range of both indirect channels (for example email, phone call, chatbox...) and direct channel to consumers and spell out the process clearly so that they know what they need to do and what the timescales and potential solutions are. Use a centralized knowledge base to underpin the customer service process, giving your agents instant access to the latest, consistent information to solve issues. This can be extended to company websites to make it easier for customers to solve simple problems themselves through self-service, maximising efficiency. Moreover, retailers also need to analyse consumers' questions and their issues to learn valuable information that can be used to improve products, processes and services.

Outcome fairness shows a positive impact on customer satisfaction in online shopping in Vietnam. In an e-service environment, the customers often feedback via website or hotline and usually do not know how they will be treated. In this case; monetary compensation, future free services, or an apology should be applied. It may not guarantee customer retention, but at least, these countermeasures make customer feel satisfied and acknowledge that the sellers respect them.

\section{Limitations and future research}

Although this study has some contributions to service and quality research literature, it has some limitations, such as selfresponse questionnaire and relatives small sample size. Because of time and budget constraints, the authors could focus only on 3 dimensions of retail recovery service and its impact on consumer satisfaction and loyalty. The future studies should be conducted with consideration of other quality aspects such as process purchase quality, product quality...in an analytical framework with expansion of sample size. In addition, moderation effects of such factors as customer experience and type of product should be studied to understand service recovery.

\section{Conclusion}

This paper has empirically investigated the impact of three first-order dimension of service recovery on satisfaction and loyalty of customer. The analytical results have shown that interactive fairness, outcome fairness, procedural fairness significantly impact on customer satisfaction which consequently leads to customer loyalty. This study suggests that customer's ability to locate and interact with technical support on a website and how a company treat the customer would significantly decide customer satisfaction and loyalty. This study enriches the e-service and quality management literature by proposing measurement dimensions of e-service recovery on customer satisfaction based on empirical evidences in a developing market. Besides, from the results and discussions in this paper, managers and stakeholders in Vietnam are provided insights into the contribution of excellent business management models, particularly e-service recovery system, to obtaining high-quality perception with customers.

\section{Acknowledgements}

This research is funded by Vietnam National University, Hanoi (VNU) under project number QG.19.44. 


\section{References}

Ahn, T., Ryu, S., \& Han, I. (2004). The impact of the online and offline features on the user acceptance of Internet shopping malls. Electronic Commerce Research and Applications, 3(4), 405-420.

Balaji, M. S., Roy, S. K., \& Quazi, A. (2017). Customers' emotion regulation strategies in service failure encounters. European Journal of Marketing, 51(5/6), 960-982.

Battaglia, D., Borchardt, M., Sellitto, M. A., \& Pereira, G. M. (2012). Service recovery: a method for assessing performance. Business Process Management Journal, 18(6), 949-963.

Cheng, B. L., Gan, C. C., Imrie, B. C., \& Mansori, S. (2019). Service recovery, customer satisfaction and customer loyalty: evidence from Malaysia's hotel industry. International Journal of Quality and Service Sciences, 11(2).

Chou, P. F. (2015). An analysis of the relationship between service failure, service recovery and loyalty for Low Cost Carrier travelers. Journal of Air Transport Management, 47, 119-125.

Collier, J. E., \& Bienstock, C. C. (2006). Measuring service quality in e-retailing. Journal of Service Research, 8(3), 260275.

De Matos, C. A., Henrique, J. L., \& Alberto Vargas Rossi, C. (2007). Service recovery paradox: a meta-analysis. Journal of Service Research, 10(1), 60-77.

Ekiz, E. H., \& Arasli, H. (2007). Measuring the impacts of organizational responses: Case of Northern Cyprus hotels. Managing Global Transitions, 5(3), 271.

Finn, A. (2011). Investigating the non-linear effects of e-service quality dimensions on customer satisfaction. Journal of Retailing and Consumer Services, 18(1), 27-37.

General Statistics Office of Vietnam. (2019) Statistical Yearbook of Viet Nam 2018, Hanoi: Statistical Publishing House.

Giao, H., Vuong, B., \& Quan, T. (2020). The influence of website quality on consumer's e-loyalty through the mediating role of e-trust and e-satisfaction: An evidence from online shopping in Vietnam. Uncertain Supply Chain Management, $8(2), 351-370$.

Gronroos, C. (1988). Service quality: The six criteria of good perceived service. Review of Business, 9(3), 10.

Hair, J. F., Ringle, C. M., \& Sarstedt, M. (2013). Partial least squares structural equation modeling: Rigorous applications, better results and higher acceptance. Long range planning, 46(1-2), 1-12.

Hess, R. L. (2008). The impact of firm reputation and failure severity on customers' responses to service failures. Journal of Services Marketing, 22(5).

Jung, N. Y., \& Seock, Y. K. (2017). Effect of service recovery on customers' perceived justice, satisfaction, and word-ofmouth intentions on online shopping websites. Journal of Retailing and Consumer Services, 37, 23-30.

Kasabov, E., \& Warlow, A. J. (2010). Towards a new model of "customer compliance" service provision. European Journal of Marketing, 44(6).

Kassim, N., \& Abdullah, N. A. (2010). The effect of perceived service quality dimensions on customer satisfaction, trust, and loyalty in e-commerce settings. Asia pacific journal of marketing and logistics.

La, S., \& Choi, B. (2019). Perceived justice and CSR after service recovery. Journal of Services Marketing, 33(2), $206-219$.

Lee, G. G., \& Lin, H. F. (2005). Customer perceptions of e-service quality in online shopping. International Journal of Retail \& Distribution Management.

Li, C. Y., \& Fang, Y. H. (2016). How online service recovery approaches bolster recovery performance? A multi-level perspective. Service Business, 10(1), 179-200.

Liang, C. C., \& Nguyen, N. L. (2018). Marketing strategy of internet-banking service based on perceptions of service quality in Vietnam. Electronic Commerce Research, 18(3), 629-646.

Maxham III, J. G. (2001). Service recovery's influence on consumer satisfaction, positive word-of-mouth, and purchase intentions. Journal of Business Research, 54(1), 11-24.

McCollough, M. A., Berry, L. L., \& Yadav, M. S. (2000). An empirical investigation of customer satisfaction after service failure and recovery. Journal of Service Research, 3(2), 121-137.

Miller, J. L., Craighead, C. W., \& Karwan, K. R. (2000). Service recovery: a framework and empirical investigation. Journal of operations Management, 18(4), 387-400.

Parasuraman, A., Zeithaml, V. A., \& Berry, L. L. (1988). Servqual: A multiple-item scale for measuring consumer perc. Journal of Retailing, 64(1), 12.

Parasuraman, A., Zeithaml, V. A., \& Malhotra, A. (2005). ES-QUAL: A multiple-item scale for assessing electronic service quality. Journal of Service Research, 7(3), 213-233.

Pham, Q. T., Tran, X. P., Misra, S., Maskeliūnas, R., \& Damaševičius, R. (2018). Relationship between convenience, perceived value, and repurchase intention in online shopping in Vietnam. Sustainability, 10(1), 156.

Proserpio, D., \& Zervas, G. (2017). Online reputation management: Estimating the impact of management responses on consumer reviews. Marketing Science, 36(5), 645-665.

Sengupta, A. S., Balaji, M. S., \& Krishnan, B. C. (2015). How customers cope with service failure? A study of brand reputation and customer satisfaction. Journal of Business Research, 68(3), 665-674.

Sousa, R., \& Voss, C. A. (2009). The effects of service failures and recovery on customer loyalty in e-services. International Journal of Operations \& Production Management, 35(3), 493-525.

Van Vaerenbergh, Y., Varga, D., De Keyser, A., \& Orsingher, C. (2019). The service recovery journey: Conceptualization, integration, and directions for future research. Journal of Service Research, 22(2), 103-119. 
Wang, X., \& Zhang, Q. (2018). Does online service failure matter to offline customer loyalty in the integrated multi-channel context? The moderating effect of brand strength. Journal of Service Theory and Practice, 28(6), 774-806.

Wicks, A. M., \& Roethlein, C. J. (2009). A satisfaction-based definition of quality. The Journal of Business and Economic Studies, 15(1), 82.

Choi, Y., \& Mai, D. Q. (2018). The sustainable role of the e-trust in the B2C e-commerce of Vietnam. Sustainability, 10(1), 291.

Zhang, M., Dai, X., \& He, Z. (2015). An empirical investigation of service recovery in e-retailing. Journal of Service Theory and Practice, 25(3), 348-367.

Zhang, M., Huang, L., He, Z., \& Wang, A. G. (2015). E-service quality perceptions: an empirical analysis of the Chinese e-retailing industry. Total Quality Management \& Business Excellence, 26(11-12), 1357-1372.

\section{Appendix (Survey questionnaire)}

Interactive Fairness (IF)

- This e-retailer communicated honestly with me about my problem

- This e-retailer seemed very concerned about my problem

- I was given a reasonable explanation as to why the original problem occurred

- The e-retailer was courteous to me when trying to resolve my problem

- I believed what the e-retailer told me about how my problem occurred

- This e-retailer gives the customer the ability to talk to a 'live' person using telephone number

- The e-retailer was sympathetic and caring

- The e-retailer put a lot of positive energy into handling my problem

- The procedures and instructions for dealing with complaints are displayed in detail and clearly on the website

- $\quad$ The e-retailer responded to me quickly

Outcome Fairness (OF)

- Compensation was offered for problem the e-retailer created

- In resolving my complaint the e-retailer gave me what I needed

- The company has various forms of compensation for customers (changing products, discount vouchers ...)

- I got what I deserved

Procedural Fairness (PF)

- The e-retailer responded quickly to my complaint

- The e-retailer adapted their complaint handling procedures to satisfy my needs

- I got a chance to tell the e-retailer the details of my problem

- The e-retailer showed flexibility in responding to my complaint

- The e-retailer made it easy for me to voice my complaint

- Overall, the e-retailer had a good procedure for dealing with complaints.

Customer Satisfaction (CS)

- In general, I (am/was) happy with the service experience

- I was satisfied with the service this e-retailer provided

- I was satisfied with the product provided by this e-retailer

Customer Loyalty (CL)

- I will recommend this e-retailer to my friends

- I intend to purchase from this e-retailer in the future

- I intend to continue to visit this e-retailer's site in the future 
(C) 2021 by the authors; licensee Growing Science, Canada. This is an open access article distributed under the terms and conditions of the Creative Commons Attribution (CC-BY) license (http://creativecommons.org/licenses/by/4.0/). 